\title{
A Check on Planning Access for Blended Learning
}

\author{
Chong Pei Yee, Zamhar Iswandono bin Awang Ismail, Esmadi Abu Abu Seman
}

\begin{abstract}
Higher learning institutions favor implementing blended learning to achieve their educational goals and learning objectives. The purpose of this review is to analyze the ideal blended learning model and the recommendations for planning future blended learning activities. Nine articles published from 2013 to 2018 which provided the frameworks or models and future suggestions were appraised. This review revealed that blended learning is not about using Information, Communication, and Technology (ICT) tools anymore but how the learning process is being blended to deliver effectiveness in learning. The review also discovered that in future blended learning design has to include collaboration among educators and how is the learning process can be applied to actual life. The culture of an educational organization is also an important focus.
\end{abstract}

Index Terms: Blended Learning, Technology in Education, Educational Framework, Curriculum Design, Higher Education

\section{INTRODUCTION}

Moving to $21^{\text {st }}$ century learning method is one of the focuses of Higher Learning Institutions. Teaching and learning concepts evolved from physical classroom to the innovations in technology. The concept of Open and Distance Learning (ODL) system that shift from the conventional teaching approach is increasing of the level in technological usage; shifting learning responsibility by giving opportunity to the learners to control their learning in their own time and place [35]. The pressure to utilize Information, Communication and Technology (ICT) at university level comes from changes in student demographic by giving the flexibility to the school leavers to pursue their degrees (Caravias, 2014) [10]. Furthermore, the study by Filippidi, Tselious and Komis (2010) [15] stated that Learning Management System (LMS) proved to bridge the distance between learners by providing learning materials. Compared to traditional learning, LMS embeds social interactions and give opportunity for the learners to become active participants. However, fully implementing e-learning tools and web-based programs in education are not the best ways to instill $21^{\text {st }}$ century learning

Revised Manuscript Received on August 19, 2019.

Chong Pei Yee, Computer Science Unit, Labuan Matriculation College, Labuan Federal Territory, Malaysia.

Zamhar Iswandono bin Awang Ismail, Faculty of Computing and Informatics, University Malaysia Sabah Labuan International Campus, Labuan Federal Territory, Malaysia.

Esmadi Abu Abu Seman, Faculty of Computing and Informatics, University Malaysia Sabah Labuan International Campus, Labuan Federal Territory, Malaysia. characteristics among the students. Web-based programs will be more effective if implemented with other methods of learning. The view is supported by Poon (2013) [37] in her paper mentioned the precaution steps

must be taken in using ICT to guide learners in their learning process and not to take over the precious interaction time between instructors and the learners. Interactive strategy will enhance students' learning experiences. Also claimed by Khlaisang and Likhitdamrongkiat (2015) [27] in their study, the combination of online learning systems in blended learning activities could improve cognitive skills for learners to pursue study in degree level.

Due to the limitation in e-learning tools, traditional face-to-face teaching methods are still favored in retaining the attention of learners. Explanations from lecturers are important as a part of contribution in learning process. Learners are able to engage their learning with face-to-face interaction in the classroom environment to provide more effective learning output. However, face-to-face classroom teaching method had been condemned as the minimal learner-centered strategy in learning where the instructors have authority to decide and evaluate students' progress (Chan and Leung, 2016) [11]. The positive transformation by merging classroom and computer mediated learning brought us to the concept of blended learning. Horn and Staker (2014) [23] stated blended learning is the correct path to go beyond the limitation of time, place, path and pace. By understanding their own learning path, students learn according to their learning needs. At this point, blended learning was introduced in education as an alternative solution. It combines both face to face learning and technology-based in delivering educational content. Blended learning provides flexibility for the learners to experience learning in various delivery modes which is most comfortable to them [20] [36]. It presumes that students are autonomous by taking ownership to learn on their own. Learners challenge themselves in different levels of learning. Thus, blended learning has the prospective to stimulate long term learning in higher education [10].

\section{BLENDED LEARNING}

Blended Learning is an important term in higher education especially in the application of the $21^{\text {st }}$ century learning method. The demand for flexibility in learning and the affordances of technology provided the impetus for the rise of blended learning (Mirriahi, Alonzo and Fox, 2015) [32]. Terms of blended 


\section{A Check on Planning Access for Blended Learning}

learning keep changing based on advancement of information technology. Generally, blended learning involves integration of face-to-face method and online technologies [9] [19] [23] [24] [36] [43]. Blended learning environment is popular in enhancing teaching and learning in most of the university courses. In blended learning model for teaching practice, Caner [9] found that well-organized blended teaching can encourage active participants among the students. Akyol and Garrison's [2] research examined that in blended learning, the frequency of activity at integration phase provide high-order thinking learning processes and outcomes compared with online course. The result from the research by Grgurovic [20] showed that students have flexibility in deciding their learning activities. Therefore, blended learning environment enables students to become autonomous learners to take control and responsible on their own learning. Caner [9] stated that blended learning can contribute in teaching professional development and increasing skills of preparing lessons in teaching. According to Gregory and Trapani [19], blended learning was able to improve planning skills for laboratory preparation. Thus, it increases the quality of learning outcomes that developed throughout their learning by demonstrating their skills and understanding in a non-theoretical session. George-Walker and Keeffe [18] stated that a successful learner must be aware of their learning needs and preferences. They will be able to find a method to fit their changing needs in their study. For this purpose, the course content development has to support learners with their own individualized blend.

One latest definition, Horn and Staker (2015) [24] explained that blended learning is a combination of three parts; through Online Learning, Supervised Brick-and-Mortar Location, and Integrated Learning Experience. Web-based tools that integrated in blended learning refer to any classroom-based learning guided by a teacher in which part of learning process happen informally outside the classroom via e-learning. Learners have the right to decide what to learn, to choose when and where they learn and to ensure their learning occur. The second part of definition is the face-to-face approach that the student learns partially in traditional classroom which monitored by educators and the learning process to be continued at home with self-study. Horn emphasized that to produce various aspects of learning experiences, learners' learning styles must be associated in the directions of blended program. The evolution of blended learning frameworks happen in every decade and have to restructure for the new research direction (Garrison, Anderson and Archer) [16].

\section{METHODOLOGY}

Articles published from 2013 to 2018 were searched in the Google Scholar and Emerald online databases. The following keywords searched include: 'blended learning', 'framework', 'model', 'higher education' and 'approach'. The papers were screened to meet the following criteria which discussed: (1) blended learning framework or model in higher learning education, (2) suggestions to implement blended learning. 


\begin{tabular}{|c|c|c|c|c|c|}
\hline & Source & Model/Approach & Objective of Paper & Tools & Sugestions \\
\hline 1 & $\begin{array}{l}\text { Lily Wong, } \\
\text { Arthur Tatuall, } \\
\text { Stephen } \\
\text { Burgess, } \\
2013\end{array}$ & $\begin{array}{l}\text { Blended Leaning } \\
\text { Arsesment (BLA) } \\
\text { framenot: }\end{array}$ & $\begin{array}{l}\text { 1. To meas ure and improve the } \\
\text { framework to be more realistic in } \\
\text { current living. }\end{array}$ & $\begin{array}{l}\text { 1. WebCT wab page } \\
\text { 2. WluminataLivetutonals }\end{array}$ & $\begin{array}{l}\text { 1. Consider the readiness to adopt. } \\
\text { 2. Ensures the effect ofblendedleaming } \\
\text { techniquain desiging blended } \\
\text { learningprogram. } \\
\text { 3. Assessmant in the quality of the } \\
\text { program towards individual blend. }\end{array}$ \\
\hline 2 & $\begin{array}{l}\text { The Shibley, } \\
\text { KatiaE. } \\
\text { Amaral, John } \\
\text { D. Shank; Lisa } \\
\text { R Shibley, } \\
\text { 2014 }\end{array}$ & $\begin{array}{l}\text { ADDIE model } \\
\text { (Analysis, Design, } \\
\text { Developmerit, } \\
\text { Implementation and } \\
\text { avaluation) }\end{array}$ & 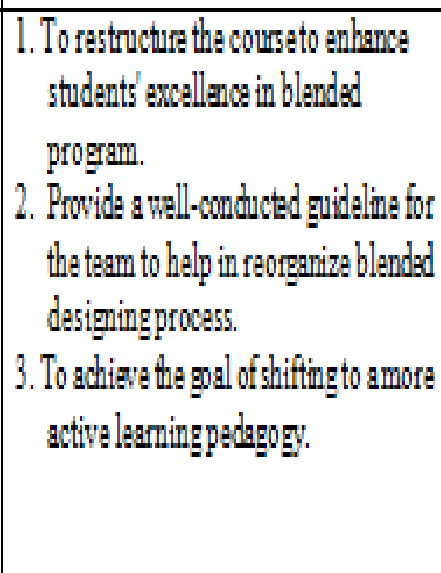 & 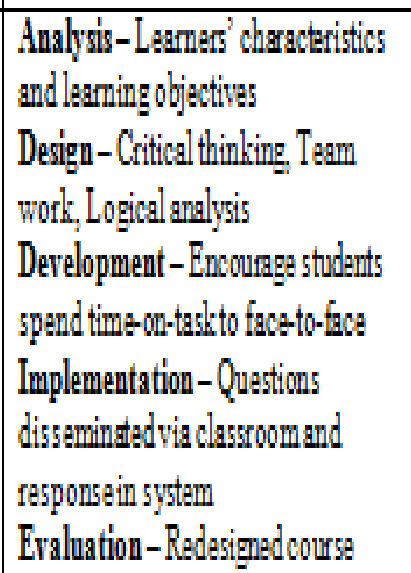 & $\begin{array}{l}\text { 1. Efficay of onious multimedia } \\
\text { componarts } \\
\text { 2. Attitudes toward collaborative } \\
\text { leaning } \\
\text { 3. The design ofblended course aims to } \\
\text { bring outmoreactiveactivities }\end{array}$ \\
\hline 3 & $\begin{array}{l}\text { Lyn M. } \\
\text { Jeffry, John } \\
\text { Milne, Gordon } \\
\text { Suddaby, } \\
2014\end{array}$ & & 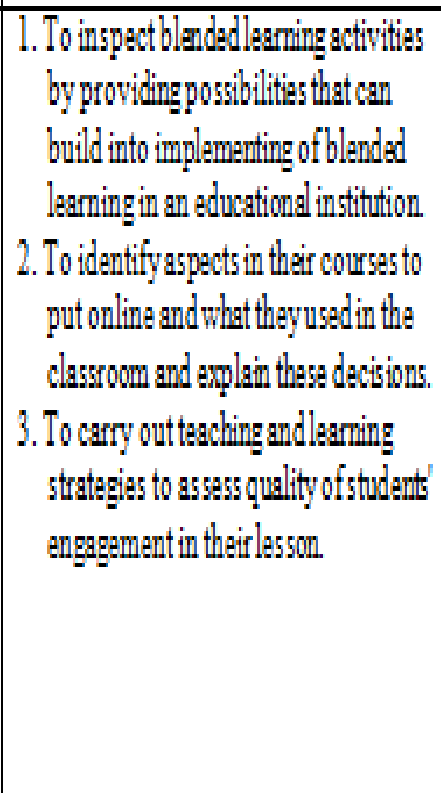 & 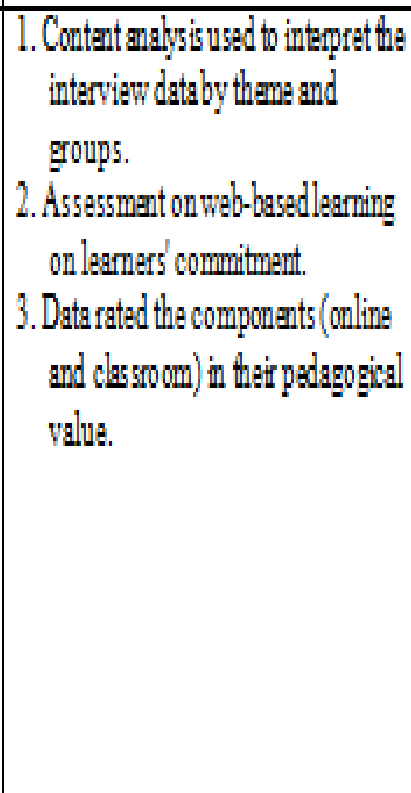 & 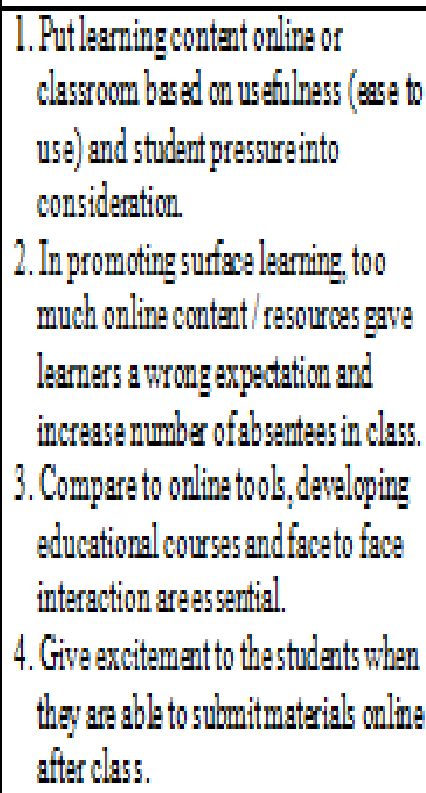 \\
\hline 4 & $\begin{array}{l}\text { Au Thien Wan, } \\
2015\end{array}$ & $\begin{array}{l}\text { Blended Leaming } \\
\text { Experienos } \\
\text { Technological } \\
\text { Framework }\end{array}$ & 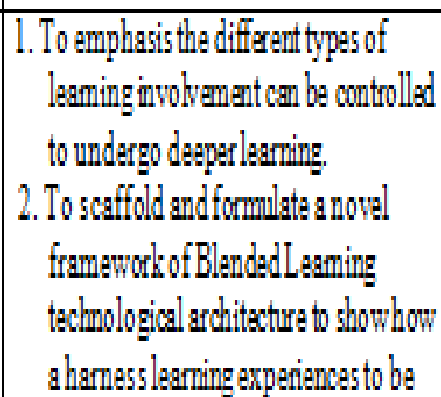 & $\begin{array}{l}\text { 1. Core component in the system: } \\
\text {-E-Laaming } \\
\text { - Back-enddatabase sytem } \\
\text { - data analygis tools } \\
\text { - faedback andrecommender system }\end{array}$ & 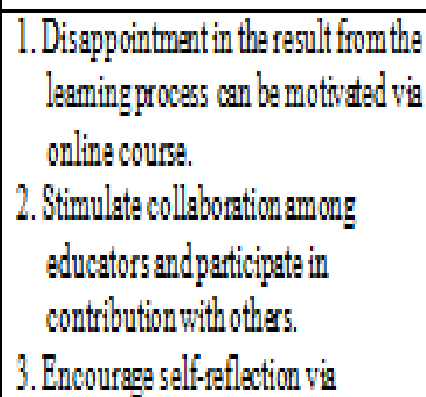 \\
\hline
\end{tabular}


A Check on Planning Access for Blended Learning

\begin{tabular}{|c|c|c|c|c|c|}
\hline & & & $\begin{array}{l}\text { analyzed and possibly be usedin a } \\
\text { feedback system. }\end{array}$ & & visualizationlearning massuremert. \\
\hline 5 & $\begin{array}{l}\text { NeginMirriahi, } \\
\text { Dennis Alons, } \\
\text { Bob For, } \\
2015\end{array}$ & $\begin{array}{l}\text { Proposed The } \\
\text { Blended Leaming } \\
\text { Framework }\end{array}$ & 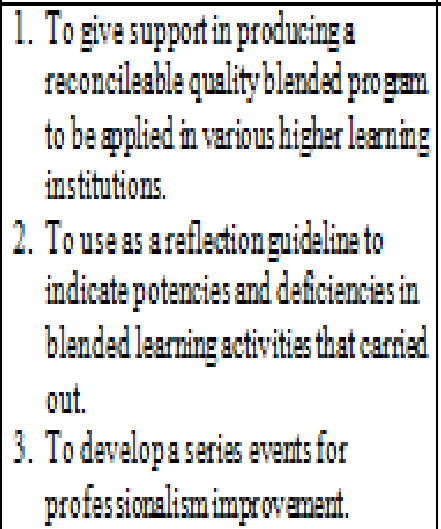 & $\begin{array}{l}\text { 1. Standardsin blendedlaming } \\
\text { framework }\end{array}$ & 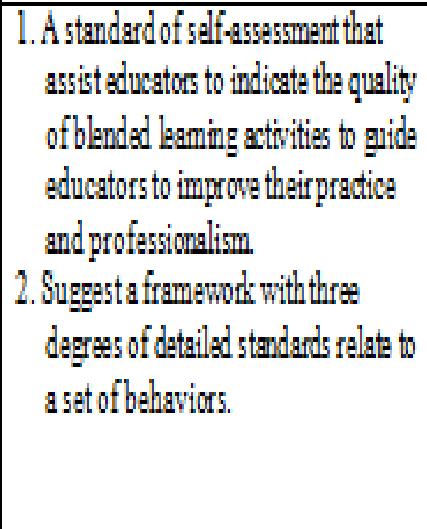 \\
\hline 6 & $\begin{array}{l}\text { AnilKumar, } \\
2016\end{array}$ & & $\begin{array}{l}\text { 1. To highlight tha impotarit of } \\
\text { techologies use in blendad laming to } \\
\text { support tacking and leaming in } \\
\text { administrationdiverity of higher } \\
\text { institutions. }\end{array}$ & 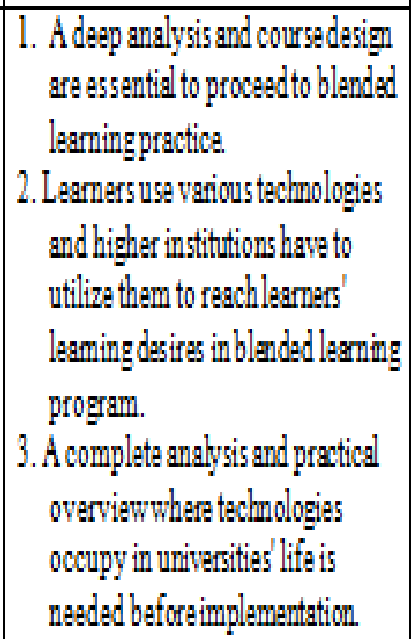 & 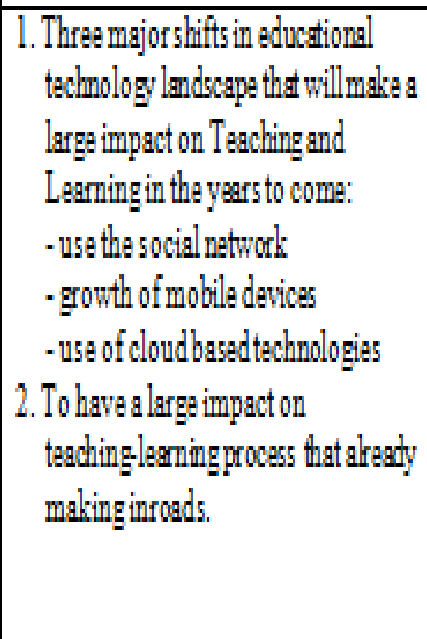 \\
\hline 7 & $\begin{array}{l}\text { Bidarfa Jose, } \\
\text { Rusman Ellan, } \\
2017\end{array}$ & $\begin{array}{l}\text { Scibnce Launing } \\
\text { Aotvitien Modsl } \\
\text { (SLMM) }\end{array}$ & 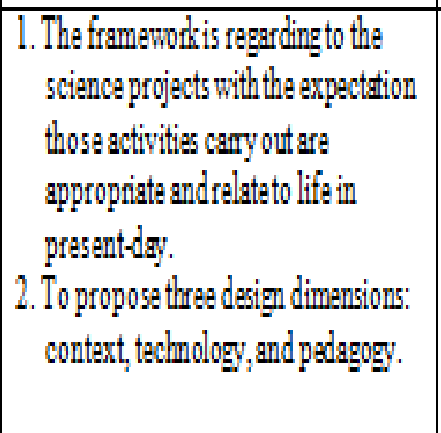 & $\begin{array}{l}\text { SLAMModal } \\
\text { 1. Context- formaland informal } \\
\text { leaning, indivitual and } \\
\text { collaborative, open and closed } \\
\text { 2. Technolog - vitual and physical } \\
\text { interaction } \\
\text { 3. Padagogy - theortical and } \\
\text { hands-onactivitiss }\end{array}$ & 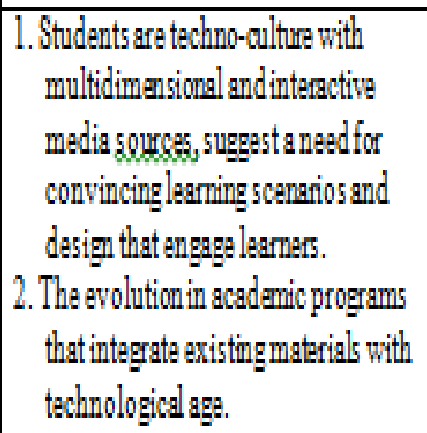 \\
\hline 8 & $\begin{array}{l}\text { Josephine } \\
\text { Adekola Vichi } \\
\text { H.M Dal, } \\
\text { Ken Gardingr, } \\
\text { 2017 }\end{array}$ & $\begin{array}{l}\text { Holistic fam aw od to } \\
\text { support effective } \\
\text { institutional } \\
\text { transitions into } \\
\text { anhancedblended } \\
\text { leaning. }\end{array}$ & 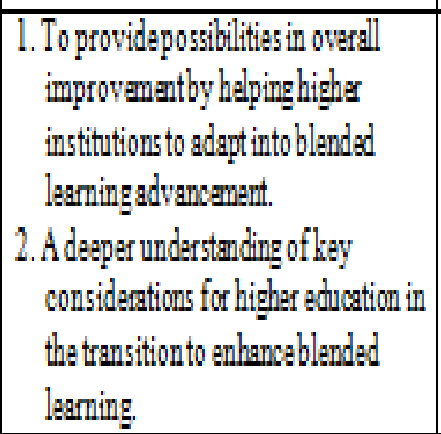 & 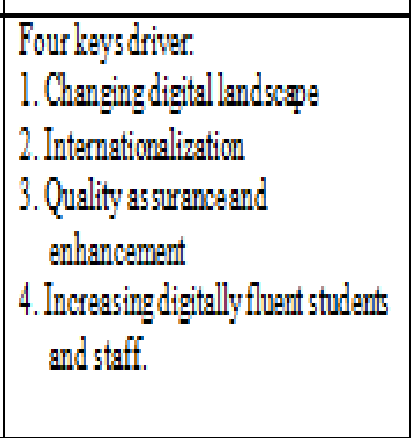 & 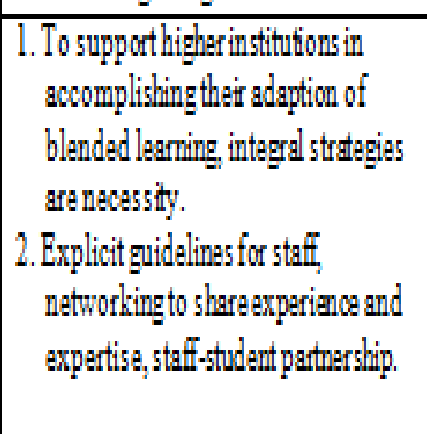 \\
\hline 9 & $\begin{array}{l}\text { PingLiaser, } \\
\text { Steven D. Taff, }\end{array}$ & $\begin{array}{l}\text { Webinar Integration } \\
\text { Tool }\end{array}$ & $\begin{array}{l}\text { 1. To indicate the ideal teaching and } \\
\text { leamingmethodvia webinar }\end{array}$ & $\begin{array}{l}\text { 1. Technology consideration: tools } \\
\text { with tas bs combination }\end{array}$ & $\begin{array}{l}\text { 1. The best practice for studerits } \\
\text { engagementis to involvemore }\end{array}$ \\
\hline
\end{tabular}




\begin{tabular}{|c|c|c|c|}
\hline $\begin{array}{l}\text { Anne } \\
\text { Murphy-Hagan, } \\
2018\end{array}$ & $\begin{array}{l}\text { incorporate with teclmologies. } \\
\text { 2. To aid institution in coordingting } \\
\text { learning outcomes with sutable } \\
\text { webinar learning tasks. } \\
\text { 3. To encourgge the developmant and } \\
\text { sharing strategies for integration and } \\
\text { designing blended learning with } \\
\text { teaching experience. }\end{array}$ & $\begin{array}{l}\text { 2. Organizing approaches with the } \\
\text { principles of leaming. } \\
\text { 3. Boost active learning with 4Es } \\
\text { (Engage, Explore, Explain \& } \\
\text { Extend) Leaning Cycle model. } \\
\text { 4. Identify factors for effective } \\
\text { learning through webinar. }\end{array}$ & $\begin{array}{l}\text { learner-centered strategies with } \\
\text { digital integration. } \\
\text { 2. Combination of digital tools and } \\
\text { applications is to give inspiration to } \\
\text { the learners to transfom themselves } \\
\text { into independent learner and partake } \\
\text { actively. } \\
\text { 3. To encourgage development, sharing } \\
\text { and establish a professional leaming } \\
\text { community to work collaboratively. }\end{array}$ \\
\hline
\end{tabular}

\section{FINDINGS}

\section{A. Blended Learning Tools}

The early trend was identified where the ICT tools played a significant role in educational process. However, due to the limitations of the ICT tools itself, the features in the e-learning tools were not enough to perform a great impact in the teaching and learning process [9] [20] [28]. Based on the data accumulated from the issued journals, it can be divided into two parts; pedagogical efforts to engage learning and integration of blended learning in real life.

Five of the nine papers published in the years between 2013 and 2015 were focusing on the affective balance; learning subjects, exploring educational theory and motivation presence. The papers proposed that social, cognitive and motivation presence have to be borne in mind with a very careful thought in designing blended learning approach. The result for these papers are discussing about effectiveness of blended learning design in developing educational content in order to produce successful learners. Therefore elements such as motivation, learning flexibility, learners' style, engagement in learning, learner-centric were emphasized in developing learning tools [9][18][19]. Overall professional preparation can be improved by identifying these key elements in the online course [3][17][40]. The papers also stressed on some other factors and features in implementing blended learning such as; warm-up activities, learning materials and interactivity to enhance learners' engagement can lead to the success of a blended learning design [8][12].

However, some researchers indicated that there were other aspects to be considered. The latest four papers between 2016 and 2018 tried to relate blended learning experience with the real world situations. Researchers raised the issue regarding the relevance of the blended learning's activities to contemporary life [7]. From the blended learning models, researchers extended blended activities by providing hands-on learning experiences and increase of digital fluent throughout educational processes and learning outcomes [1] [7].

\section{Future Planning}

In the future planning approach for blended learning in an education institutional is more to how they blend their learning process. The suggestions from nine articles split into three aspects; professional development, technological efficacy and relevant to real life.

In promoting future blended learning, collaboration can increase communication among course members; among the instructors and students [4][21][31]. Integration of collaborative models will give a spark to the instructors to design blended activities creatively and increase curiosity among students. It can be done by establish professional learning community (PLC) as a platform of collaborative sharing [30]. Pye, Holt, Salzman, Bellucci, \& Lombardi (2015) [39] suggested a general blended learning design and activities are needed because teaching staffs might implement their own strategies as their own contribution. It will be the crucial element of blended learning which allow faculty to evaluate and develop learning community to share the best practices among them (Napier, Dekhare \& Smith, 2011) [35]. This is important because most of the educators are from different background and generation; even some of them have not experienced it during their own education (Moskal, Dziuban and Hartman, 2013) [33]. Schools become true learning communities; capable of adapting approaches and models to meet their unique needs (Tucker et al., 2017) [42]. Adekola, Dale, \& Gardiner, 2017 [1] outlined the future development of blended learning will gather the educators to share expertise and experience in a networking environment and it is better to have explicit guidelines. Thus, the integration of blended learning will be a part of institutions culture to work collaboratively among educators and students. Tucker, Wycoff and Green, (2017) [42] stated effective teamwork as a culture in blended learning that instilled in the organization is more important than the learning strategies itself.

In the aspect of technological efficacy, Kumar (2016) [29] suggested educational technology tools that will give a great influence in the future for learning purpose are mobile devices, social networking and cloud technologies. Dinning et al. (2015) [13] claimed that applications in information technology engage students effectively throughout their learning progress. Social media becomes a popular platform among the learners that allows them to convey their thoughts in and after formal

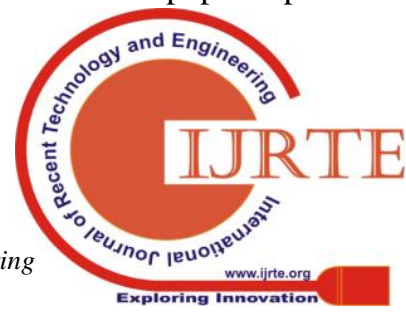


session and assists learners to construct their ideas (Chan and Leung, 2016) [11]. Facebook and Twitter will a better option in supporting peer exchanges and cooperative learning by assigning individual tasks and defend arguments [26][39]. However, Pye et al. (2015) [39] argued that mobile devices only allowed limited downloading and the use of learning resources which are more suitable to hold an online discussion or to keep track of dates. To overcome this shortage, Jeffrey, Milne and Suddaby (2014) [25] recommended the method and strategies of blended learning have to move to classroom engagement strategies and encourage interaction between the students.

The impacts of Industrial Revolution 4.0 (IR 4.0) influence Education 4.0 which shaped by innovations can lead to the major changes in education aspects; delivery of pedagogy, the content and the structure of education. In the initiative to produce graduates to fulfill the jobs in era of IR 4.0, highly creative, critical thinking, innovative, self-learning skills, communication and collaboratively skills will be far important than ever. Therefore, Bidarra and Rusman (2017) [7] suggested that future design of blended learning course must be realistic and able to be transferred to actual environment. The structure of blended learning must be able to deliver skills to the students to make lifelong learning a permanent part in real life. To impart in-depth learning among the students, Shibley, Amaral, Shank, and Shibley (2014) [41] suggested that the new educational course should include critical thinking and logical analysis elements when designing a blended course. In the cognitive domain based on Bloom's model, students should be able to apply, analyze, evaluate and create with the knowledge they have. To provide students with better learning experience, enhancement of blended learning with own pace learning system is needed which is independent of time and place.

\section{DISCUSSION \& RESULTS}

The adoption of blended learning has been favored in learning contexts in degrees. Many higher institutions are trying to apply blended learning in educational process. Therefore, various frameworks of designing and evaluating blended learning can be found in the review. However, none of the frameworks to be recognized as the best practice for implementing blended learning in higher institutions. Each educational institution designed their framework according to their own understanding of blended learning, pedagogical approaches, and academics judgements on appropriate tools that consider to be used. It can be concluded that the framework was tailored according to the needs of certain institutions and did not fulfill criteria in all perspectives in educational purposes. Mirriahi et al. (2015) [32] in her paper also stated it was one of the challenges to bring blended learning into advancement of academic practice because the available frameworks are problematics regarding to particular aspects such as the outline and standard of blended learning.Furthermore, the review also describes the meaning of blended learning were not explained properly. The boundary and limitation of blended learning were according to the educational purpose of different higher learning institutions. The interpretation of blended learning was defined in accordance to the interest of the educational organization. An institution must identify their own definition of blended learning so that the implementation of blended learning's strategies can be designed to fulfill their learning directions to provide learning experiences in the contexts of higher institution. It is useful in helping an institution to select a suitable learning model to meet their learning climate. Ma'arop and Embi (2016) [31] in their paper argued that it is difficult to determine the ideal blend between face-to-face with web-based learning due to shortage and insufficient of knowledge and applied skills to conduct the blended program. Similarly, as mentioned by Moskal et al.(2013)[33] there is no "one method matches all" strategy or technique to ensure success.

\section{CONCLUSION AND RECOMMENDATION}

The achievement of blended learning only can be determined with the continuous effort over several years. The culture of an organization plays a vital role to the success or failure of a blended learning initiative that undertaken to meet education climate of certain educational institutions. The current blended learning approaches are not merely to the use of technology, but the most important results come from the learning gains by the students from any educational effort. Besides students' engagement, professional development is one of the main concerns in the process of designing blended learning. In the meantime, educators may take an initial step to look forward by integrating learning technologies in IR 4.0 in the blended environment. The flexibility of the usage of technologies or gadgets such as smart phone, tablets can be widespread use to gain learning experience. Learning is not just on desktop or laptop any more. In accordance with the rise of gadget usage, applications in the smart phone become more popular and offer variety choices to the users. Students hold their gadgets most of the time to search information any time anyway.

The realistic of blended learning in learning process become one of the requirements in future planning. Arguments occurred on how the learning process can be related to the real world. Therefore, it is recommended to bridge the $21^{\text {st }}$ century learning elements into the blended learning design. The main four components that have to be interconnected with the $21^{\text {st }}$ Century teaching and learning process are collaboration, critical thinking, communication, and creativity. The outcomes of learning in $21^{\text {st }}$ century are focused on skills, knowledge and proficiency to triumph in career and survive to live. The combination of $21^{\text {st }}$ century learning components in blended learning is to navigate humans' life and working environment to support lifelong learning. 


\section{REFERENCES}

1. J. Adekola, V. H. M. Dale, and K. Gardiner, "Development of an institutional framework to guide transitions into enhanced blended learning in higher education," Res. Learn. Technol., 2017.

2. Z. Akyol and D. R. Garrison, "Understanding cognitive presence in an online and blended community of inquiry: Assessing outcomes and processes for deep approaches to learning," Br. J. Educ. Technol., 2011.

3. B. E. Aguinaldo, "Implementing Blended Learning in an Impoverished Academic Institution Using a Bricolage Approach Model," Int. J. Inf. Educ. Technol., 2013.

4. A. T. Wan, "How Can Learners Learn from Experience? A Case Study in Blended Learning at Higher Education," Int. J. Inf. Educ. Technol. 2014.

5. C. J. . Auster causter@fandm.edu, "Blended Learning as a Potentially Winning Combination of Face-to-face and Online Learning.," Teach. Sociol., 2016.

6. Farahiza Zaihan Azizan, "Blended learning in higher education institution in Malaysia.," in Proceedings of Regional Conference on Knowledge Integration in ICT 2010, 2010.

7. J. Bidarra and E. Rusman, "Key pedagogical and technological factors for effective blended learning design," in The Envisioning Report for Empowering Universities, 2017.

8. H. Çakır and B. A. Bichelmeyer, "Effects of teacher professional characteristics on student achievement: an investigation in blended learning environment with standards-based curriculum," Interact. Learn. Environ., 2016

9. M. Caner, " A blended learning model for teaching practice course.," Turkish Online Journal of Distance Education - TOIDE, 2010

10. V. Caravias, "Teachers' Conceptions and Approaches to Blended Learning: A Literature Review," Int. J. Innov. Digit. Econ., 2015.

11. W. T. Y. Chan and C. H. Leung, "The Use of Social Media for Blended Learning in Tertiary Education," Univers. J. Educ. Res., 2016.

12. W. S. Cheung and K. F. Hew, "Design and evaluation of two blended learning approaches: Lessons learned," Australas. J. Educ. Technol. 2011.

13. T. Dinning, C. Magill, J. Money, B. Walsh, and S. Nixon, "Can a Blended Learning Approach Enhance Students ' Transition Into Higher Education? a Study To Explore Perceptions, Engagement and," Int. J. Adv. Educ. Soc. Sci., 2015

14. R. Donnelly, "Harmonizing technology with interaction in blended problem-based learning," Comput. Educ., 2010.

15. A. Filippidi, N. Tselios, and V. Komis, "Impact of Moodle Usage Practices on Students ' Performance in the Context of a Blended Learning Environment," in Social Applications for Lifelong Learning, 2010.

16. D. R. Garrison, T. Anderson, and W. Archer, "The first decade of the community of inquiry framework: A retrospective," Internet High. Educ., 2010.

17. R. Garner and E. Rouse, "Social presence - connecting pre-service teachers as learners using a blended learning model," Student Success, 2016.

18. L. de George-Walker and M. Keeffe, "Self-determined blended learning: A case study of blended learning design," High. Educ. Res. Dev., 2010.

19. S. J. Gregory and G. Di Trapani, "A blended learning approach to laboratory preparation," Int. J. Innov. Sci. Math. Educ., 2012.

20. M. Grgurovic, "Blended Learning in an ESL Class: A Case Study," CALICO J., 2014.

21. B. Güzer and H. Caner, "The Past, Present and Future of Blended Learning: An in Depth Analysis of Literature," Procedia - Soc. Behav. Sci., 2014.

22. D. Holley and M. Oliver, "Student engagement and blended learning: Portraits of risk," Comput. Educ., 2010.

23. M. B. Horn and H. Staker, "Blended learning is about more than technology," Education Week, 2014.

24. M. B. Horn and H. Staker, Blended : Using Innovation to improve schools. USA: Jessey-Bass, 2015.

25. L. Jeffrey, J. Milne, G. Suddaby, and A. Higgins, "Blended Learning: How Teachers Balance the Blend of Online and Classroom Components," J. Inf. Technol. Educ. Res., 2017.

26. E. Kassens-Noor, " Flip, move, tweet: A blended course design for different learning environments in urban planning, sustainability, and climate change university courses," Int J. Scholarship Technol. Enhanced Learn., 2016.

27. J. Khlaisang and M. Likhitdamrongkiat, "E-learning System in Blended Learning Environment to Enhance Cognitive Skills for Learners in Higher Education," Procedia - Soc. Behav. Sci., 2015.
28. B. Kistow, "Blended learning in higher education: A study of a graduate school of business, Trinidad and Tobago," Caribb. Teach. Sch., 2011.

29. A. Kumar, "Student perspective on blended learning in higher education." Int. Innov. Res. Develop., 2016.

30. P. Lieser, S. D. Taff, and A. Murphy-Hagan, "The Webinar Integration Tool: A Framework for Promoting Active Learning in Blended Environments," J. Interact. Media Educ., 2018.

31. A. H. Maarop and M. A. Embi, "Implementation of Blended Learning in Higher Learning Institutions: A Review of Literature," Int. Educ. Stud., 2016.

32. N. Mirriahi, D. Alonzo, and B. Fox, "A blended learning framework for curriculum design and professional development," Res. Learn. Technol., 2015.

33. P. Moskal, C. Dziuban, and J. Hartman, "Blended learning: A dangerous idea?," Internet High. Educ., 2013.

34. N. H. Nanclares and M. P. Rodriguez, "Students' Satisfaction with a Blended Instructional Design: The Potential of 'Flipped Classroom' in Higher Education," J. Interact. Media Educ., 2016.

35. N. P. Napier, S. Dekhane, and S. Smith, "Transitioning to blended learning: Understanding student and faculty perceptions," $J$. Asynchronous Learn. Netw., 2011.

36. A. G. Picciano, "Blending with purpose: The multimodal model," $J$. Asynchronous Learn. Netw., 2009.

37. J. Poon, "Blended Learning: An Institutional Approach for Enhancing Students' Learning Experiences," J. Online Learn. \&amp; Teach., 2013.

38. W. W. Porter, C. R. Graham, K. A. Spring, and K. R. Welch, "Blended learning in higher education: Institutional adoption and implementation," Comput. Educ., 2014.

39. G. Pye, D. Holt, S. Salzman, E. Bellucci, and L. Lombardi, "Engaging diverse student audiences in contemporary blended learning environments in Australian higher business education: Implications for design and practice," Australas. J. Inf. Syst., 2015.

40. P. Shea and T. Bidjerano, "Learning presence: Towards a theory of self-efficacy, self-regulation, and the development of a communities of inquiry in online and blended learning environments," Comput. Educ., 2010.

41. K. E. Amaral, J. D. Shank, I. Shibley, and L. R. Shibley, "Designing a blended course: Using ADDIE to guide instructional design," J. Coll. Sci. Teach., 2015.

42. C. R. Tucker, T. Wycoff and J. T. Green, Blended Learning in Action: A Practical Guide Toward Sustainable Change. Corwin: California, USA, 2017.

43. L. Wong, A. Tatnall, and S. Burgess, "A framework for investigating blended learning effectiveness," Educ. Train., 2014.

\section{AUTHORS PROFILE}

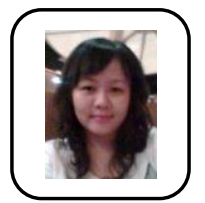

Chong Pei Yee is a lecturer on computer science subject at Labuan Matriculation College, Computer Science Department under Ministry of Education, Malaysia. She is a master's degree holder in Master of Science (Information Technology-Education) from University of Technology Malaysia. She graduated in degree of Technology with Education from University of Technology Malaysia. Most of her research works relate to teaching and learning methods. She has published five papers in twenty first century teaching and learning to bring public matriculation towards independent learning. She was awarded with Distinction of Service for her excellence service in the college. Currently, she further her study in $\mathrm{PhD}$ of Information Technology at University Malaysia Sabah, Labuan International Campus as part time student.

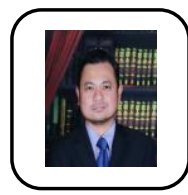

Dr. Zamhar Iswandono bin Awang Ismail is a senior lecturer in Faculty of Computing \& Informatics, University Malaysia Sabah. He graduated Ph.D. in Informatics at The University of Manchester, Manchester, United Kingdom. $\mathrm{He}$ is holding M. Sc. in Information Systems Engineering from UMIST, Manchester, United Kingdom. He finished his degree and diploma at University of Technology Malaysia in Computer Science. Areas of research include information system, digital entertainment (computer games), action case and gamification. Head of Information Systems Research Group is a post he is holding currently. He had experience as a Deputy Dean (Academic \& Student Affairs) and (Research \& Innovation). He is also one of the Programme Assessor for Games Development and Creative Multimedia in Malaysian Qualifications Agency (MQA). He has published 15 publications relate to his field. Research Awards that received 


\section{A Check on Planning Access for Blended Learning}

include Gold Award IUCEL 2018 for "Gamed-ECG Gamification Platform", Silver Award ITEX 2018 for "Gamed-ECG Gamification Platform", Silver Award ITEX 2018 for "ThesauriGame: Gamification-based App", Gold Award PEREKA 2017 for "ThesauriGame: Gamification-based App", Silver Award PEREKA 2017 for "AUVIMED: Basics of Muscoskeletal System", Gold Award PEREKA 2017 for "Gamed-ECG Gamification Platform", and Silver Award IUCEL 2017 for "ThesauriGame: Gamification-based App". Distinction of Service was awarded three times by University Malaysia Sabah for his excellence service in university. He is also a member of Malaysian Qualifications Agency: Programme Assessor, Association of Information Systems

(Malaysian Chapter) and Manchester United Supporters Trust. Dr. Zamhar received invitation as speaker to deliver knowledge in his field. Besides that, he is also research supervisor from bachelor's degree to $\mathrm{PhD}$ levels.

Esmadi Abu Abu Seman is a senior lecturer in Faculty of Computing \& Informatics, University Malaysia Sabah. $\mathrm{He}$ is a $\mathrm{PhD}$ holder in Information Science from National University Malaysia. He studied MSc in Data Telecommunications \& Networks at University of Salford. He graduated his degree of BIT in System Science \& Management National University Malaysia. He has published 11 papers in different journals and proceedings. He received five times Distinction of Service by University Malaysia Sabah for his excellence service in university. He is also a member of International Association of Computer Science and Information Technology (IACSIT). Besides that, he is also research supervisor from bachelor's degree to $\mathrm{PhD}$ levels. Dr. Esmadi received invitation as speaker to deliver knowledge in his field. Besides that, he is also research supervisor from bachelor's degree to $\mathrm{PhD}$ levels. 